His literary activity was great and varied. The treatise on magnetism and electricity known as Carey Foster and Porter's edition of JoubertAtkinson was far more than a mere translation of Joubert's work, and reflects, in considerable measure, Porter's skill as a teacher. His articles on surface tension in the fourteenth edition of the "Encyclopædia Britannica" and on thermal expansion in the "Dictionary of Applied Physics", are excellent examples of Porter's massive learning and powers of clear exposition, and his capacity for throwing new light on an old problem is admirably shown in his presidential address to Section A (Mathematical and Physical Sciences) of the British Association at Glasgow in 1928, an address which dealt with the Volta effect and some problems in thermo-electricity.

One of Porter's earlier books, a treatise on elementary mechanics, is less widely known than its merits deserve. It was one of the first elementary books to inculcate sound teaching concerning the nature of mass, and the whole subject is developed by easy stages and by the use of the simplest mathematics to a point at which the reader is introduced to the solution of problems concerning the twodimensional motion of a rigid body. Porter was also the author of two monographs on thermodynamics and on the method of dimensions, and completed, with a considerable measure of success, the difficult task of bringing out a new and revised edition of Preston's "Theory of Light".

Porter was always at his happiest when handling problems dealing with the manifestations of surface energy, and of late years had occupied himself with the calculation of the form of the capillary surface of revolution, giving special attention to the region in which the ordinary methods of approximation are of little use. In these calculations, he never lost sight of the needs of the experimenter, and his results are of great assistance to those concerned with the determination of capillary constants.

Porter's services to physies on the administrative side were most valuable. For many years he acted as secretary to the University of London Board of Studies in physics; he was one of the founder fellows, and the first honorary secretary, of the Institute of Physics. In this last-named capacity he played no small part in forming and in guiding the policy of the newly formed institution. $\mathrm{He}$ was president (1913-14) of the Röntgen Society, and president (1920-22) of the Faraday Society. At the time of his death, he was one of the editors of the Philosophical Magazine.

Porter was temperamental, and, like most temperamental men, was apt, on occasion, to take up hurriedly a completely indefensible position-and thoroughly to enjoy defending it. He was all the more lovable on that account, for his mind and outlook were always generous, and it is with real and deep sorrow that his many friends of all ages realize that they have looked their last upon the eyes kindly twinkling behind their gold-rimmed spectacles, and that they can no longer call upon that great store of ordered knowledge that was always so readily placed at their disposal.

\section{Prof. T. W. Todd}

THE death was announced from Cleveland, Ohio, on December 28, 1938, of Prof. Thomas Wingate Todd, anatomist and anthropologist, at the age of fifty-three years. $\mathrm{He}$ was born at Sheffield, England, in 1885, and entered the University of Manchester as a student of medicine, graduating in 1907. His attention was originally devoted to surgery; he became a fellow of the Royal College of Surgeons of England in 1911. His early love for anatomy reasserted itself, and he entered the anatomical department of his university as demonstrator and then as lecturer under Prof. Young and later under Sir Grafton Elliot Smith. His first research was on the relationship of cartilage and bone cells to bone formation. Incidental observations led him to infer that certain changes in the coats of arteries were due to pressure on sympathetic nerves.

In 1912, Todd was invited to the chair of anatomy in the Western Reserve University, Cleveland, Ohio. His colleague in physiology was another British subject, the late Prof. J. J. R. Macleod. He had occupied his chair for twenty-six years at the time of death, and had extended his department to many times its original dimensions. The researches carried out by him were of a threefold nature. When he wished to settle such simple matters as the order in which epiphyses unite with their shafts, the times at which the sutures of the skull close, the changes which the human face undergoes from childhood to adolescence, the changes undergone by the bones of the skeleton from maturity to old age, the manner and extent to which male bones differ from those of women, he discovered that such questions could not be answered because there was nowhere in the world a collection of human skeletons of which the age and sex were known. He set to work and slowly accumulated within his department skeletons of white Americans and of American Negroes, of known age and sex. At the time of his death this standard collection contained more than three thousand skeletons, besides skeletons of mature and immature animals-especially of those which most nearly approach man in structure. Fellow researchers joined him from many parts of the world; paper after paper dealing with age and sex changes as manifested in his collections of human skeleton appeared in the American Journal of Physical Anthropology, the American Journal of Anatomy, the Journal of Anatomy and the Anatomical Record during the past twenty years.

During the last twelve years of his life, Todd organized a survey of the growth changes in childhood. With the aid of the Brush Foundation, he obtained opportunities and means of keeping eight hundred children, born in Cleveland to well-off parents, under observation from infancy to full maturity. Four times yearly each child was examined medically and physically and records made-especially X-ray records-of the growth changes in their bones. His aim was to obtain a series of stages which would serve as a standard of the normal for medical men and especially for school medical officers. In 
1937, appeared the first volume of his results, under the title of an "Atlas of Skeletal Maturation" (St. Louis, 1937). This first volume contains 75 plates giving X-ray photographs of the human hand, each plate representing a certain stage of normal growth. Subsequent volumes were to deal with the growth of other parts and regions of the human body.

Todd made the alimentary tracts of his students the subject of a systematic X-ray survey, his object being to determine what might be the normal dispatch of a bismuth meal in healthy young men, and the extent to which the normal may be departed from within the range of health. His observations were summed up in his Beaumont Lectures of 1930 and published in book form under the title "Behaviour Pattern of the Alimentary Tract".

Todd's object was to lay sure and wide foundations on which other workers might build. He lived and worked to the utmost limit of his bodily and mental strength. He sowed on an immense-an almost unprecedented-scale; it was when he harvested and especially when he came to thresh out and market his grain that his life's endeavour fell short of greatness. ARThur KeIth.

\section{Mr. S. H. Ray}

Mr. Sidney Herbert Ray, whose death was recently announced, was born in London on May 28, 1858. In January 1882 he was appointed by the London School Board as assistant master in the Olga Street School, Bethnal Green, a position which he held until his retirement in May 1923. He was twice married, but had no children. He died on January 1, 1939. By unremitting labour, combined with a peculiar gift for languages, he raised himself to an honoured position in linguistic science. A noticeable characteristic of Ray was the absence of self-seeking ; he worked under conditions which a less devoted man might well have found impossible. Nothing daunted his enthusiasm, and he became a recognized expert in a neglected field of linguistics.

This is not the place to detail his numerous papers on Papuan, Melanesian and Polynesian languages. On suitable occasions he exposed those who juggled with words in order to support vain theories of origins, for the construction of a language and its phonology were to him of prime importance. His studies of particular languages, however, afforded a basis for those wider surveys in which he gave to students the benefit of his erudition.

In 1892, Ray read a paper on the languages of British New Guinea at the Ninth International Congress of Orientalists, in which he showed definitely that there are languages in Now Guinea that differ in vocabulary and grammar from the Melanesian and Polynesian spoken in western Oceania and also from the undoubtedly Melanesian of south-east New Guinea. These non-Melanesian languages he named Papuan as a convenient term for numerous distinct languages with archaic features; about the same time, W. Schmidt made the same deduction for German New Guinea. In 1894, Ray recorded traces of
Papuan languages in various islands of Melanesia. In the same year he demonstrated that the Motu and allied languages of south-east New Guinea were not eastern Polynesian, as had been believed, but were Melanesian. He regarded the languages of the Masim area as originally Papuan upon which have keen grafted words and idioms from Melanesian tongues. Their Papuan origin accounts for their diversity, and the Melanesian element, which is common throughout the area, accounts for their partial agreements.

When Ray visited Torres Straits and British New Guinea (Papua) as a member of the Cambridge Anthropological Expedition to Torres Straits in 1898, he for the first time was able to study various languages from the mouths of the natives, and he was untiring in his endeavour to make the most of his opportunities. His assiduity was such that he continually reduced his informants to exhaustion, while he himself remained quite fresh. In 1907 he published, as volume 3 of the Reports, a monumental work on the languages of New Guinea, which extended and confirmed his previous deductions. He proved that the western language of Torres Straits belonged to the same group as those of northern Australia, and that the eastern language was Papuan and allied to certain languages of the extreme west of Papua.

In 1926, Ray published a comparative study of the Melanesian languages, a further proof of his industry and erudition. In Melanesia there is a linguistic sub-stratum which differs from island to island. Upon this was grafted an immigrant Melanesian language which had spread at an early date from Indonesia and through its simpler grammar and facility of expression obscured the radical differences of the older languages. Later there were colonists from Indonesia who settled mainly on some of the smaller islands and introduced a pidgin-tongue. The words can only rarely be referred to any one original Indonesian language and they form only a small proportion of the vocabulary of any single language. The linguistic diversity in parts of Melanesia suggests that the Melanesian languages were originally variant stocks and that their apparent uniformity has been brought about by the influx of Indonesian words and idioms. This was the first of a projected series of studies, but the expense of their publication prevented the appearance of further volumes. In more favourable circumstances, Ray could have enriched linguistic science to a much greater extent; we can only marvel that, handicapped as he was, he accomplished so much work that will have a lasting value.

\section{A. C. Haddon.}

\section{Prof. E. H. Hall}

Prof. Edwin Herbert Hall, emeritus professor of physics in Harvard University, whose death occurred on November 20, devoted most of his life to the study and investigation of electric conduction. $\mathrm{He}$ will doubtless be most remembered by the Hall effect which he discovered in 1878. This effect is the production of an electromotive force when an electric 